\title{
Vascular plants of Azerbaijan: a supplement for an updated checklist of pteridophytes and gymnosperms
}

\author{
Rashad A. Salimov ${ }^{1}$ \\ Parvana Kh. Garakhani \\ Zenfira S. Aliyeva \\ Institute of Botany, Azerbaijan National Academy of Sciences, \\ Badamdar 40, Baku, AZ1004, Azerbaijan
}

\begin{abstract}
An updated checklist of plant species increases knowledge about flora available for a given area and are fundamental to the public awareness and conservation of plant diversity. These kinds of achievements are closely linked to the implementation of Global Strategy for Plant Conservation Target 1 . This paper provides a supplement for an updated nomenclatural checklist of the non-flowering vascular flora of Azerbaijan, one of the main plant diversity center in the Caucasus. Information on taxonomy and nomenclature of nonflowering vascular plants, an updated list of the accepted names and principal synonyms of the taxa of native and xenophyte plants known to occur in Azerbaijan are presented in the checklist. Their distribution and life form, rarity and endemic status are also quantitatively analyzed. It includes 115 species, 27 infraspecific taxa (subspecies and varieties) and 11 natural hybrids of native and naturalized non-flowering vascular plants of Azerbaijan belonging to 22 families and 50 genera. After the publication of the first volume of Flora of Azerbaijan about 50 new taxa were recorded as a result of studies by various researchers. The nomenclatural changes were done among 28 taxa according to recent phylogenetic and systematic investigations of relevant plant groups. An up to date nomenclatural checklist will be a key text to develop e-flora of Azerbaijan and is necessary for future systematics, ecology, physiology, ethnobotany and phytochemistry in Azerbaijan.
\end{abstract}

Key Words: Azerbaijan, pteridophytes, gymnosperms, vascular plants, taxonomy

\section{INTRODUCTION}

According to Target 1 of the 2011-2020 Global Strategy for Plant Conservation (GSPC) of the United Nations' Convention on Biological Diversity (CBD), one of the widely accessible Flora of all known plant species is

Accepted for publication: 8 May 2020

1'E-mail: resad_selimov@yahoo.com. a fundamental requirement for plant conservation. Additionally, a number of global initiatives have been established to promote the implementation of the GSPC and provides a baseline for the achievement and monitoring of other targets of the Strategy beyond 2020 [Miller, Ulate, 2017; Sharrock et al., 2018].

Since 2014 as a participating member of the World Flora Online Consortium, an international collaborative project that meets the goals of the GSPC Target 1, the Institute of Botany of the National Academy of Sciences of Azerbaijan has been purposefully working on the development of electronic flora of Azerbaijan. Within this purpose as a very first basis, a prerequisite of the floristic inventory of Azerbaijan is the need to develop online taxonomic resources and the mechanism for updating the online flora of Azerbaijan.

In the last decade, the checklist of diatomic algae (Bacillariophyta) of the continental reservoirs of Azerbaijan [Mukhtarova, Jafarova, 2020] and diversity and taxonomic structure of Cyanoprokaryota in the Azerbaijan sector of the Caspian Sea [Nuriyeva, 2019a, b] have been updated. These products that we envisage for the near future to publish in the online database. On the other hand, developing an up to date version of the checklists bryophytes and vascular plants for Azerbaijan are an ongoing projects of the Institute of Botany.

Historically, the first comprehensive floristic works to study the vegetation of Azerbaijan were conducted by A.A. Grossheim. He summarized all prior works and published first edition Flora Azerbaijan [19341936]. During the 1930s and 1960s, the vegetation of Azerbaijan was further studied by A.A. Grossheim, I.I. Karyagin, R. Rzazade, Y. Isayev, H. Gadirov, S. Aghajanov, R. Askerova and V. Hajiyev, where floristic work had turned to the monographic style, taxonomy had broadened into systematics and experimental taxonomy. A team of these enthusiastic botanists under the editorship of I.I. Karyagin was published the most complete 8 volumes of the Flora Azerbaijan [1950-1961] which remains in use today and is the indispensable reference of all botanists. The next steps over the years, several new botanical studies have been made by Azerbaijani researchers such as R. Askerova, V. Hajiyev, G. Akhundov, L. Prilipko, A. Askerov, etc. and foreign scientists. 
Since botanical names and ranks are changed as a result of systematic and nomenclatural researches, the accumulation and interpretation of data never cease. Therefore there was a need to provide the current classification and nomenclature of these plants readily accessible through the indexing of all names. Within this context Vascular Plants of Azerbaijan is intended to be the first complete synonymized checklist of the native, xenophytic and adventive vascular plants, with current classifications and nomenclature. The first volume of the Vascular Plants of Azerbaijan dealt with the complete list of the native and naturalized flora of nonflowering families, including lycopods and other fern-allies, as well as the gymnosperms [Salimov et al., 2019]. It brings together information from specimens deposited at Herbarium of the Institute of Botany (BAK) as well as many relevant publications.

Our goal in this paper is to provide a supplement of the in-depth analysis for an updated nomenclatural checklist of the nonflowering vascular plants that are known to occur in Azerbaijan, one of the main plant diversity center in the Caucasus. This way, any person who deals with Azerbaijan plants will find the abovementioned checklist useful.

\section{MATERIAL AND METHODS}

The studies conducted by the authors were based on extensive systematic literature review and herbarium work, including analysis of herbarium specimens deposited at the BAK.

During the preparation of the checklist, the $1 \mathrm{st}$ volume Flora of Azerbaijan [Karyagin, 1950] was consulted as an initial step to prepare a list of taxa that provides overall vision of all useful information for compiling the list. In addition to this preparatory, the floras [Tahtadzjan, 1954; Davis, 1965; Ketskhoveli, 1971; Azadi, 2017] and checklists [Czerepanov, 1995; Gagnidze, 2005; Caucasian Flora Conspectus, 2003; Murtazaliev, 2009] of the adjacent countries, as well as many taxonomic and floristic publications [Askerov, Bobrov, 1972a, b; Askerov 1977, 1983, 2001, 2016; Askerov et al., 2015, 2016; Farzaliyev, 2008; Ibrahimov, 2006; Imkhanitskaya, 1990, 2003; Kudrjashova, Popova, 2008; Mammadov, 2011; Prilipko, 1961; Qurbanov, Farzaliyev, 2013, 2017; Safarov, Farzaliyev, 2019; Talybov, 2001; Talybov, 2014] dealing with the Azerbaijan flora and existing information in the virtual herbarium and various online databases such as Euro+Med PlantBase [2019], GBIF, The flowering world [2019], IPNI [2019], The Biodiversity Heritage
Library [BHL, 2019], Azerbaijan Plant Data Service [AZBIMM, 2019] have been utilized for the compilation of the detailed literature and brought numerous taxonomic and nomenclatural changes. We kept track of those data sources in order to verify the scientific names of accepted taxa and their synonyms, standard abbreviations of authors via checking the related protologue of each taxon comprehensively.

Abbreviations of the authors' names follow those proposed by R.K. Brummitt \& C.E. Powell [1992]. For the entries, titles of periodicals with botanical content have been abbreviated according to the BPH-2 (comprising the second edition of Botanico-PeriodicumHuntianum. Pittsburgh) [Bridson et al., 2004]. Book titles have been abbreviated as in Stafleu \& Cowan, TL-2 (Taxonomic Literature Second edition) [Stafleu, Cowan, 1976-1988].

The concept of families and genera adopted in the checklist corresponds to the classification of a liner sequence of extant families and genera of lycophytes and ferns [Christenhusz et al., 2011a], Pteridophyte Phylogeny Group of 2016 (PPG I), and the linear classification of existing gymnosperms [Christenhusz et al., 2011b] with some exceptions. The families here recorded with three parts of the numbers which represented by total genera as well as their total taxa number (including native and xenophyte species, subspecies, varieties and natural hybrids); the cosmopolite and endemic taxa to Azerbaijan [Solomon et al., 2013]; and the threatened species [Solomon et al., 2013; Red Book of Azerbaijan, 2013]. The life-form categories for the terrestrial and aquatic plant species have followed the systems of Raunkiaer [1934] and subsequent extensions by Ellenberg \& Mueller-Dombois [1967]. The distribution data are also provided based on records from 20 botanical regions of Azerbaijan.

\section{RESULTS AND DISCUSSION}

There are 22 families, 50 genera, 115 species, 27 infraspecific taxa and 11 natural hybrids of native and naturalized non-flowering vascular plants from Azerbaijan in the checklist (Fig. 1). With the current knowledge, there are 37 species, 1 subspecies and 1 hybrids of non-native vascular plants (xenophytes), belonging to 19 genera and 5 families (Table 1).

When analyzing the diversity of families at the genus level the 10 most genus-rich families have at least two genera and together include 38 genera, which account for $76 \%$ of the total genus richness. of the nonflowering vascular flora of Azerbaijan (Fig. 2). 


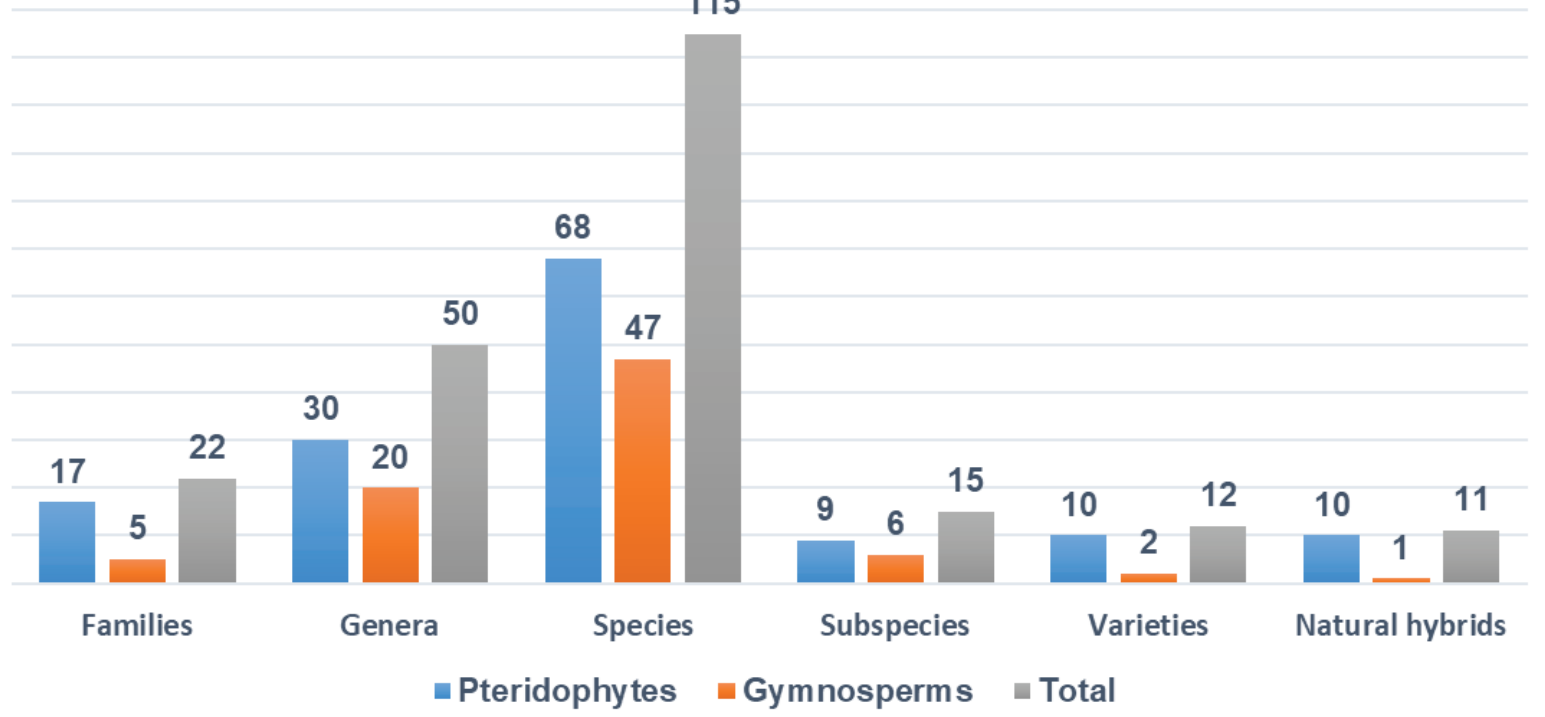

Figure 1. Total taxa number of families, genera, species, subspecies, varieties and natural hybrids.

Table 1. The total genera and infraspecific taxa number within the families.

\begin{tabular}{|c|c|c|c|c|c|c|c|c|c|c|}
\hline \multirow[b]{2}{*}{ Families } & \multirow[b]{2}{*}{$\begin{array}{l}\frac{\pi}{0} \\
\stackrel{0}{0} \\
\circlearrowleft\end{array}$} & \multicolumn{4}{|c|}{ Native } & \multicolumn{3}{|c|}{ Xenophytes } & \multirow[b]{2}{*}{ 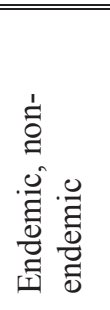 } & \multirow[b]{2}{*}{ 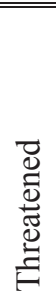 } \\
\hline & & 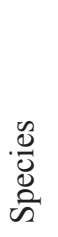 & $\begin{array}{l}\tilde{0} \\
\frac{0}{0} \\
0 \\
\tilde{0} \\
0 \\
\tilde{E} \\
\tilde{n}\end{array}$ & 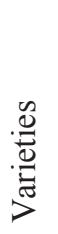 & 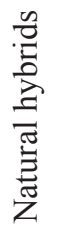 & $\begin{array}{l}\frac{\mathscr{d}}{\tilde{D}} \\
\frac{D}{n}\end{array}$ & $\begin{array}{l}0 \\
\frac{0}{0} \\
0 \\
0 \\
0 \\
= \\
\tilde{D}\end{array}$ & $\begin{array}{l}\frac{n}{0} \\
\stackrel{0}{0} \\
\text { 吾 }\end{array}$ & & \\
\hline \multicolumn{11}{|c|}{ PTERIDOPHYTES } \\
\hline Aspleniaceae Newman & 1 & 7 & 4 & 1 & & & & & & \\
\hline Athyriaceae Alston & 1 & 1 & & 2 & & & & & & \\
\hline Cystopteridaceae Shmakov & 2 & 3 & 1 & & & & & & & \\
\hline Dennstaedtiaceae Lotsy & 1 & 1 & 1 & & & & & & & \\
\hline Dryopteridaceae Herter & 2 & 19 & 2 & 4 & 9 & & & & 5,29 & 1 \\
\hline Equisetaceae Michx. ex DC. & 1 & 7 & & & 1 & & & & & 1 \\
\hline Lycopodiaceae P.Beauv. & 1 & 1 & & & & & & & & 1 \\
\hline Marsileaceae Mirb. & 1 & 2 & & & & & & & & \\
\hline Ophioglossaceae Martinov & 3 & 4 & & & & & & & & \\
\hline Onocleaceae Pic.Serm. & 1 & 1 & & & & & & & & \\
\hline Osmundaceae Martinov & 1 & 1 & & & & & & & & \\
\hline Polypodiaceae J.Presl \& C.Presl & 1 & 3 & 1 & 3 & & & & & & \\
\hline Pteridaceae E.D.M.Kirchn. & 6 & 8 & & & & & & & & 1 \\
\hline Salviniaceae Martinov & 2 & 2 & & & & & & & & \\
\hline Selaginellaceae Willk. & 1 & 1 & & & & & & & & \\
\hline Thelypteridaceae Ching ex Pic.Serm. & 3 & 3 & & & & & & & & \\
\hline Woodsiaceae Herter & 2 & 4 & & & & & & & 1,3 & \\
\hline \multicolumn{11}{|c|}{ GYMNOSPERMS } \\
\hline Cupressaceae Gray & 12 & 3 & 3 & 1 & & 19 & & 1 & & \\
\hline Ephedraceae Dumort. & 1 & 5 & 2 & & & 1 & & & & \\
\hline Ginkgoaceae Engl. & 1 & & & & & 1 & & & & \\
\hline Pinaceae Spreng. ex F. Rudolphi & 4 & 1 & & 1 & & 15 & 1 & & 1,17 & \\
\hline Taxaceae Gray & 2 & 1 & & & & 1 & & & & \\
\hline Total & 50 & 78 & 14 & 12 & 10 & 37 & 1 & 1 & 7,146 & 4 \\
\hline
\end{tabular}




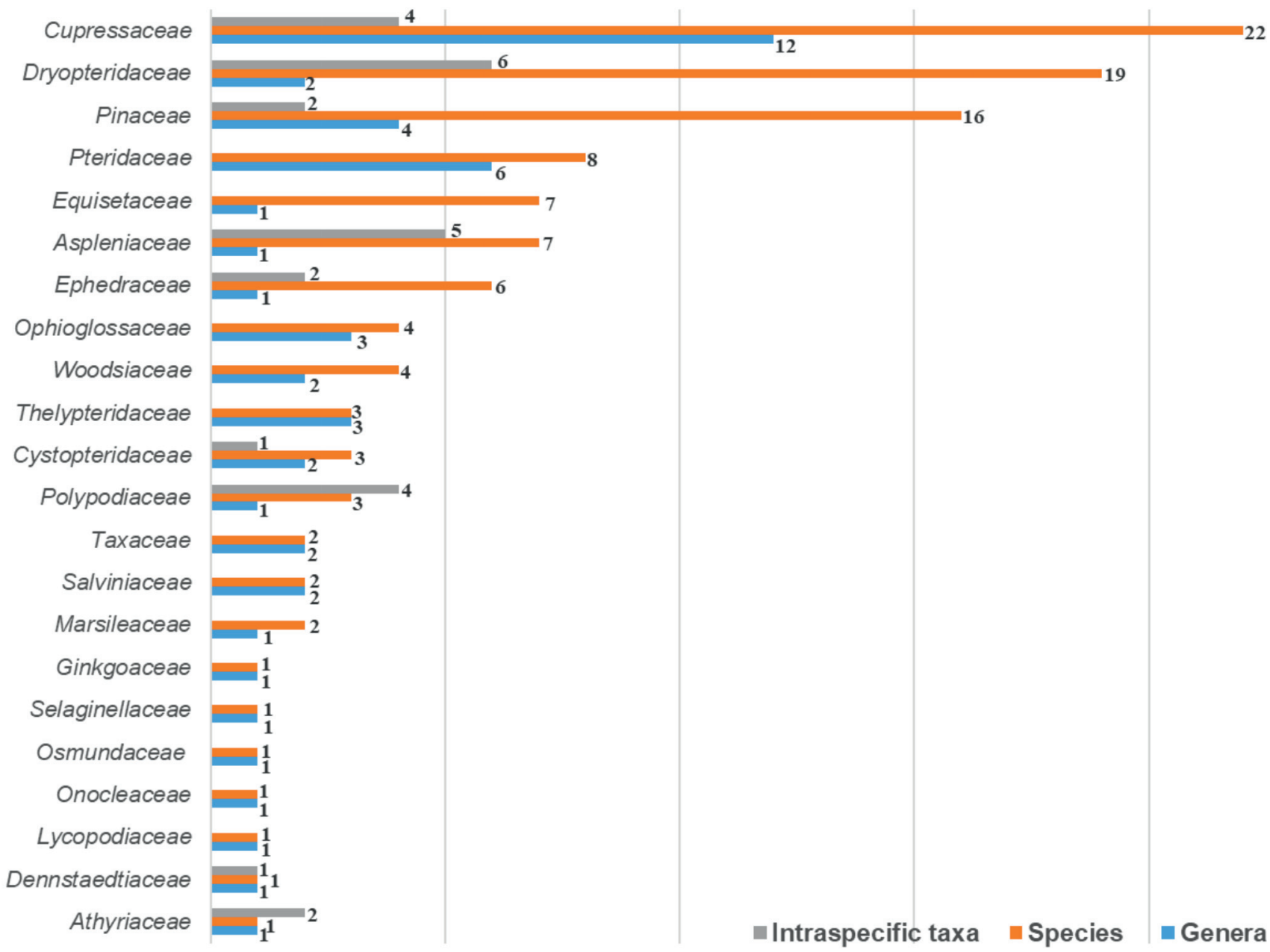

Figure 2. The ranking of species-rich families of non-flowering vascular flora.

The most genus-rich families within gymnosperms are Cupressaceae and Pinaceae, with 12 and 4 genera, respectively, and among pteridophytes are Pteridaceae, Ophioglossaceae and Thelypteridaceae with 6 genera and 3 genera each, respectively. The most 9 species-rich families together include 93 species representing 80.9\% of all non-flowering species of Azerbaijan. In another hand, there are 7 families with only one species each, 3 families with two species each, and 3 families with three species each.

In view of climatic and geographic diverse conditions, mainly mountain parts and mesophilic plant association of forests of the Greater and Lesser Caucasus as well as Talysh represents biodiversity centres for non-flowering vascular plants (Table 2, Fig. 3). Among them, the Lankaran lowlands and Western Greater Caucasus stand out in terms of species diversity followed by the Northern Lesser Caucasus, the Quba part of the Greater Caucasus, and the Mountain part of Lankaran. The high species-rich for Absheron is mostly due to large datasets from introduced and cultivated gymnosperms used in landscape design and botanical gardens.

By comparing different regions of Azerbaijan, the most species-poor regions are Samur-Devechi and Caspian lowlands, Bozgir plateau and Lankaran-Mugan with less than 6 species (Table 2).

According to present knowledge, the families in the richest in the endemic taxa in the non-flowering vascular plants of Azerbaijan are Dryopteridaceae, with five species, followed by Woodsiaceae and Pinaceae with one species each. Among these species Dryopteris raddeana (Fomin) Fomin, D. talyschensis (Askerov \& A.E.Bobrov) Askerov \& Aktcay, Polystichum kadyrovii A.Askerov \& A.Bobrov, and Pinus eldarica Medw. are national endemics, whereas Dryopteris oreades Fomin, Polystichum woronowii Fomin, Woodsia fragilis (Trevis.) T. Moore are endemics of Caucasus.

Each non-flowering vascular plant species occurring in Azerbaijan were analyzed in regard to plant response to unfavorable conditions and classified into 
Table 2. The total taxa number (including families, genera, species, subspecies, varieties and hybrids) of non-flowering vascular plants in each botanical-geographical region of Azerbaijan (from 1 to 20 indicated in the figure 3).

\begin{tabular}{clcccccc}
\hline \hline № & Botanical-geographical region & Families & Genera & Species & Subspecies & Varieties & Hybrids \\
\hline 1 & Samur-Devechi lowlands & 4 & 4 & 5 & 1 & & \\
2 & Caspian lowlands & 4 & 4 & 6 & & & 2 \\
3 & Guba part of the Greater Caucasus & 16 & 21 & 37 & 8 & 2 & 4 \\
4 & Eastern (AZ) Greater Caucasus & 11 & 13 & 15 & 5 & & 1 \\
5 & Western (AZ) Greater Caucasus & 18 & 31 & 51 & 4 & 4 & 1 \\
6 & Alazan-Ayrichay valley & 10 & 13 & 15 & 1 & & 3 \\
7 & Bozgir plateau & 4 & 4 & 5 & 3 & & \\
8 & Gobustan & 9 & 10 & 17 & 4 & & 1 \\
9 & Absheron & 8 & 26 & 50 & 3 & & 2 \\
10 & Kur plain & 8 & 10 & 11 & 2 & & 1 \\
11 & Kur-Araz lowland & 10 & 10 & 16 & 3 & & \\
12 & Northern (AZ) Lesser Caucasus & 15 & 26 & 47 & 8 & 2 & \\
13 & Central (AZ) Lesser Caucasus & 14 & 19 & 31 & 6 & & \\
14 & Southern (AZ) Lesser Caucasus & 11 & 14 & 21 & 4 & & \\
15 & Mountain part of Nakhchivan & 9 & 13 & 18 & 6 & & \\
16 & Nakhchivan plain & 9 & 11 & 16 & 3 & & \\
17 & Lankaran Mugan & 1 & 1 & 1 & & & \\
18 & Mountain part of Lankaran & 14 & 18 & 37 & 6 & & \\
19 & Lankaran lowlands & 19 & 32 & 55 & 5 & 6 & \\
20 & Diabar & 9 & 10 & 15 & 4 & & \\
\hline
\end{tabular}

C. Raunkiaer's life-form categories modified by H. Ellenberg \& D. Mueller-Dombois. From the evaluation of all these taxa, 152 of species and infraspecific taxa perennate, whereas only 1 species is an annual plant (Fig. 4). The overall spectrum of pteridophytes of Azerbaijan

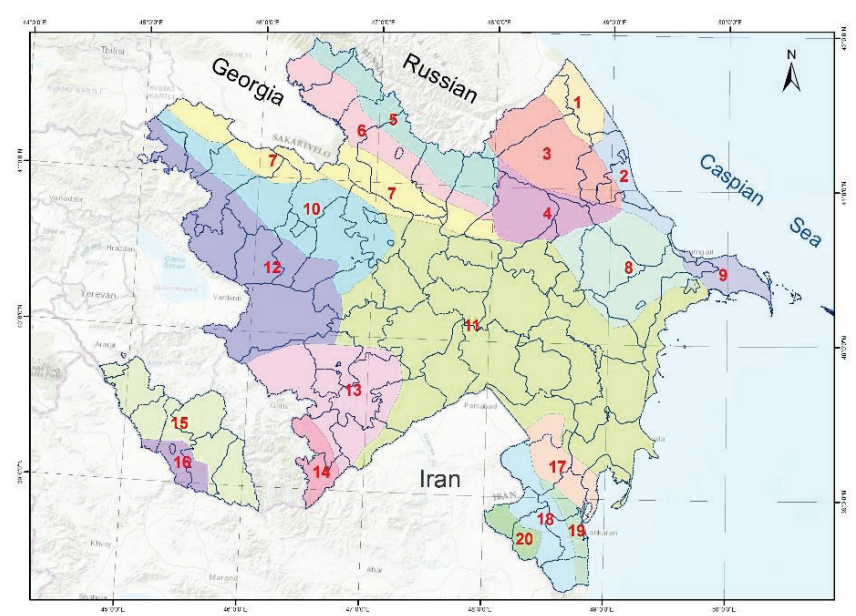

Figure 3. The botanical geographical division of Azerbaijan after Prilipko, 1960 [Salimov et al., 2018] correlates very well with the general climatic conditions of the country. Nearly $60 \%$ of all non-flowering vascular plants represent the life-form of hemicryptophyte and geophyte. The predominance of woody plants (phanerophytes (50 taxa) and chamaephytes (5 taxa)) recorded among gymnosperms.

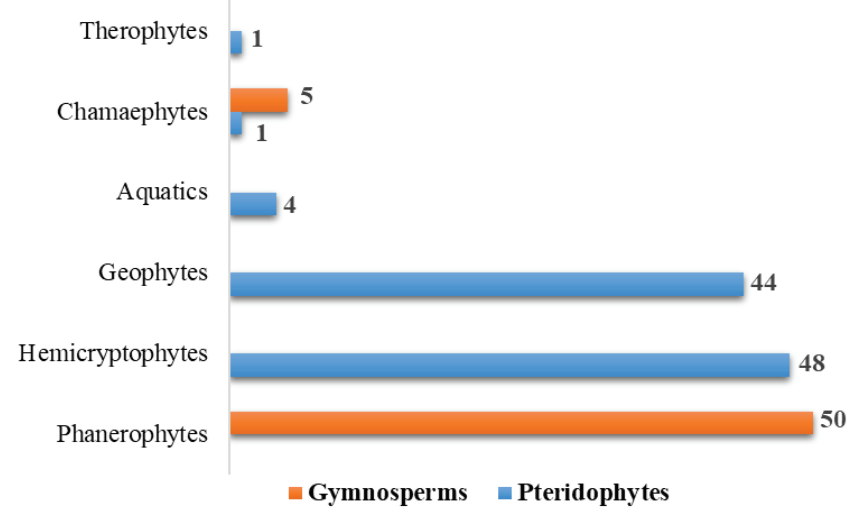

Figure 4. Plant life-form categories represented among the non-flowering vascular plants of Azerbaijan. 


\section{ACKNOWLEDGMENTS}

The authors are grateful to the Prof. Dr. Peter Wyse Jackson (USA), Prof. Dr. Sergei Mosyakin (Ukraine), Prof. Dr. Svetlana Litvinskaya (Russia), Dr. Gerald Parolly and Dr. Eckhard von Raab-Straube (Germany), Nicolas Turland (Germany), Prof.Dr. Irada Huseynova (Azerbaijan), Prof. Dr. Valida Alizade (Azerbaijan), Prof. Dr. Magsud Qurbanov (Azerbaijan), Dr. Vahid Farzaliyev (Azerbaijan) for their valuable constructive comments, additions and improvements.

\section{REFERENCES}

Askerov A.M., Bobrov A.E. (1972a) To the taxonomy of some genera of ferns from Talysh. Journal of Botany. Moscow \& Leningrad (St.Petersburg), 57 (10): 1296-1300. [А.М. Аскеров и А.Е. Бобров (1972а) К систематике некоторых родов папоротников из Талыша. Ботанический журнал, Москва и Ленинград (Санкт-Петербург), 57(10): 12961300.]

Askerov A.M., Bobrov A.E. (1972b) Ferns of Talysh. Journal of Botany. Moscow \& Leningrad (St. Petersburg), 57(11): 1412-1419. [А.М. Аскеров и А.Е. Бобров (1972б) Папоротники Талыша. Ботанический журнал, Москва и Ленинград (Санкт-Петербург), 57(11): 1412-1419]

Askerov A.M. (1977). Pteridophyta in Azerbaijan. Journal of Botany. Moscow \& Leningrad (St. Petersburg), 62(7): 1022-1030. [А.М. Аскеров (1977) Pteridophyta Азербайджана. Ботанический журнал, Москва и Ленинград (Санкт-Петербург), 62(7): 1022-1030]

Askerov A.M. (1983) System of Caucasus Ferns. Notes on the taxonomy and geography of plants. (Notulae systematicae ac Geographicae Instituti Botanici). Tiflis. 39: 3-8. [A.M. Аскеров (1983) Система папоротников Кавказа. Заметки по систематике и географии растений. Тифлис. 39: 3-8]

Askerov A.M. (2001) Ferns of the Caucasus. Baku, "Elm", 244 p. [А.М. Аскеров (2001) Папоротники Кавказа. Баку, “Элм”, 244 стр.]

Askerov A.M., Akçay U., Verdiyeva L.N. (2015) Taxonomic review of the genus Dryopteris Adans. s. str. in Azerbaijan. Proceedings of Azerbaijan NAS, Biological and Medical Sciences, 2: 129-135.

Askerov A., Akçay U., Salimov R. (2016) New taxa of fern (Dryopteris Adans. s. str.) spread over Azerbaijan Republic. YoungScientistUSA. Natural
Science., 6: 3-10.

Askerov A.M. (2016) The plant world of Azerbaijan. Baku: TEAS Press. 444 p. [A.M. Osgərov (2016) Azərbaycanın bitki aləmi. Bakı: TEAS Press. 444 s.]

Azadi R. (2017) 'Pteridophyta' (87. 'Ophioglossaceae', 88. 'Psilotaceae', 89. 'Osmundaceae', 90. 'Marsileaceae', 91. 'Salviniaceae', 92. 'Dennstaedtiaceae', 93. 'Pteridaceae', 94. 'Aspleniaceae', 95. 'Thelipteridaceae', 96. 'Woodsiaceae', 97. 'Blechnaceae', 98. 'Onocleaceae', 99. 'Dryopteridaceae', 100. 'Polypodiaceae') / Rahaman Azadi. - [Teheran]: Research Institute of Forests and Rangelands. 183 p.: ill.- (Flora of Iran / ed. M. Assadi ... [et 1.]; 87100). - ISBN 978-964-473-396-3.

AZBIMM (2019) Version 2.1.2. Published on the Internet; http://www.azbimm.az/ (accessed 10th October 2019).

Bridson G.D.R. (compiler), Townsend, S. T. (editor), Polen, E. A. (editor) and Smith, E. R. (editorial assistant). BPH-2; periodicals with botanical content constituting a second edition of BotanicoPeriodicum-Huntianum. Hunt Institute of Botanical Documentation, Carnegie Mellon University, Pittsburgh: 2004. 2 volumes. Pp xx, 1470.

Brummit R.K., Powell C.E. (Eds) (1992) Authors of Plant Names. Royal Botanic Gardens, Kew. Caucasian Flora Conspectus (2003) St. Petersburg: Univ. Press, 1: $204 \mathrm{p}$.

Christenhusz M.J.M., Zhang X.-C., Schneider H. (2011a) A linear sequence of extant lycophytes and ferns. Phytotaxa, 19: 7-54.

Christenhusz M.J.M., Reveal J.L., Farjon A., Gardner M.F., Mill R.R., Chase M.W. (2011b) A new classification and linear sequence of extant gymnosperms. Phytotaxa, 19: 55-70. doi:10.11646/ phytotaxa.19.1.3.

Cherepanov C.K. (1995) Vascular plants of Russia and adjacent states (former USSR). St. Petersburg, p. 990

Ellenberg H., Mueller-Dombois D. (1967) A key to Raunkiaer plant life forms with revised subdivisions. Ber. geobot. Inst. eidg. tech. Hochschule Rubel, 37: 56-73.

Euro+Med: Euro+Med PlantBase - the information resource for Euro-Mediterranean plant diversity: http://ww2.bgbm.org/EuroPlusMed/ [accessed 10 November 2019].

Farzaliyev V.S. (2018) Species diversity, bioecological 
features \& economic significance of Coniferales of Azerbaijan. Synopsis of doctoral dissertation thesis. Baku. 45 p. [V. S. Fərzəliyev (2018) Azərbaycanın iynəyarpaqlı bitkilərinin növmüxtəlifliyi, bioekoloji xüsusiyyətləri və iqtisadi əhəmiyyəti. Biologiya üzrə elmlər doktoru elmi dərəcəsi almaq üçün təqdim edilmiş dissertasiyanın avtoreferatı. Bak1, 45 s.]

Gagnidze R. (2005) Vascular plants of Georgia: A nomenclatural checklist. Tbilisi: Georgian Academy of Sciences.

GBIF Home Page. Available from: https://www.gbif. org [10 November 2019].

Ibrahimov A. Sh. (2006) About the new family of Azollaceae (Salviniales, Polypodiophyta) for the flora of Azerbaijan and the Caucasus. Journal of Botany, Moscow \& Leningrad (St.Petersburg), 91(6): 967968. [Ибрагимов А.Ш. (2006) О новом семействе Azollaceae (Salviniales, Polypodiophyta) для флоры Азербайджана и Кавказа. Ботанический журнал, Москва и Ленинград (Санкт-Петербург), 91(6): 967-968]

Imkhanitskaya N.N. (1990) Critical note on the Caucasian species of the section Juniperus of the genus Juniperus L. (Cupressaceae). Novosti Sistematiki Vysshikh Rastenii. Moscow, Leningrad (Novitates Systematicae Plantarum Vascularium). 27: 5-16. [Имханицкая Н.Н. (1990) Критическая заметка о кавказских видах секции Јuniperus рода Juniperus L. (Cupressaceae), Москва и Ленинград (Санкт-Петербург), 27: 5-16]

Imkhanitskaya N.N. (2003) Abstract of the Caucasian species of the genus Ephedra (Ephedraceae) I.Section Ephedra. Journal of Botany (Botanicheskii Zhurnal). Moscow \& Leningrad [St.Petersburg]. 88 (5): 139-148. [Имханицкая Н.Н. (2003). Конспект кавказских видов рода Ephedra (Ephedraceae). I. Секция Ephedra. Ботанический журнал, Москва и Ленинград (Санкт-Петербург). 88(5): 139-148]

IPNI (2019) International Plant Names Index. Published on the Internet http://www.ipni.org, The Royal Botanic Gardens, Kew, Harvard University Herbaria \& Libraries and Australian National Botanic Gardens. [Retrieved 10 November 2019].

Karjagin I.I. (Ed.) (1950) Flora of Azerbaijan. Baku. 1: 15-80. [Карягин И.И. (ред.) (1950) Флора Азербайджана. Баку. 1: 139-148]

Kudrjashova G.L., Popova T.N. (2008) A.M. Askerov. Caucasian ferns. Baku: Elm, 2001. 244 p. ГКудряшова Г.Л., Попова Т.Н. (2008) А.М. Аскеров. Папоротники Кавказа. Баку: Элм, 2001. 244 c.]

Mammadov T.S. (2011) Azerbaijan dendroflora. Baku: Elm, 1:310 p. [T.S. Məmmədov (2011)Azərbaycanın dendrofloras1. Bak1: Elm, 1: $310 \mathrm{s.}]$

Miller C., Ulate W. (2017) World flora online project: an online flora of all known plants. Biodiversity Information Science and Standards, 1: e20529. doi: 10.3897/tdwgproceedings.1.20529

Mukhtarova Sh.C., Jafarova S.K. (2020) Checklist of Diatomic Algae (Bacillariophyta) of the Continental Reservoirs of Azerbaijan. International Journal on Algae, 22(1): 25-32. doi: 10.1615/InterJAlgae.v22. i1.20

Murtazaliev R.A. (2009) Conspectus of the flora of Dagestan. V. 1: (Lycopodiaceae - Urticaceae). Makhachkala: Epokha, 319 p. [Р. А. Муртазалиев (2009). Конспект флоры Дагестана. Т. 1: (Lycopodiaceae - Urticaceae). Махачкала: Эпоха, 319 c.]

Nuriyeva M.A. (2019a) The blue-green algae of the Azerbaijani sector of the Caspian Sea. Baku: Elm, 93 p. [Nuriyeva M.Ә. (2019a) Xəzər dənizinin Azərbaycan sektorunun göy-yaşıl yosunları. Bak1: Elm, 93 s.]

Nuriyeva M.A. (2019b) Diversity and taxonomic structure of Cyanoprokaryota in the Azerbaijani sector of the Caspian Sea. Plant \& Fungal Research, 2(2): 2-10. doi.org/10.29228/ plantfungalres.50

PPG I (2016) A community-derived classification for extant lycophytes and ferns: PPG I. Journal of Systematics and Evolution, 54(6): 563-603. doi. org/10.1111/jse.12229

Prilipko L.I. (1961) Trees and shrubs of Azerbaijan. Baku: Azerneshr, 1: 321 р. [Л.И. Прилипко (1961) Деревья и кустарники Азербайджана. Баку: Азернешр, 1: $321 \mathrm{c.}]$

Qurbanov M.R., Farzaliyev V.S. (2013) Taxonomy, biomorphological and radiological features of pines. Baku, Elm, 72 p. [M.R. Qurbanov, V.S. Fərzəliyev (2013) Şamların taksonomiyası, biomorfoloji və rentgenoloji xüsusiyyətləri. Bakı: Elm, 72 s.]

Qurbanov M.R., Farzaliyev V.S. (2017) Biological and radiological characteristics of Cupressus. Baku: Elm, 62 p. (In Azerbaijani) [M.R. Qurbanov, V.S. Fərzəliyev (2017) Sərvlərin bioekoloji və rentgenoloji xüsusiyyatləri. Bakı: Elm, 62 s.]

Raunkiaer C. (1934) The life forms of plants and 
Stastistical Plant Geography. London: Oxford University Press, $632 \mathrm{p}$.

Red Book of the Republic of Azerbaijan. Rare and endangered plant and mushroom species (2013) Second edition. Baku: East-West Publish House, $670 \mathrm{p}$.

Safarov H.M., Farzaliyev V.S. (2019) The flora and vegetation cover of Hyrcanian National Park. Baku: Elm, 296 p. [Səfərov H.M., Fərzəliyev V.S. (2019) Hirkan Milli Parkının florası və bitki örtüyü. Bakı: Elm, $296 \mathrm{~s}$.]

Salimov R.A., Garakhani P.Kh., Aliyeva Z.S. (2019) Vascular Plants of Azerbaijan: a nomenclatural checklist of nonflowering plants. Baku, Azerbaijan. $64 \mathrm{p}$.

Salimov R., Karimov V., Babayeva Z., Gasimova G., Aliyeva Z., Akbarova A., Fatdayeva A., Nabiyeva P., Isgandarova A., Hajiyeva S. (2018) Vascular plants of Azerbaijan: a nomenclature update and survey of Lamiaceae L. Plant \& Fungal Research, 1(1): 69-85.

Sharrock S., Hoft R., Dias B.F.S. (2018) An overview of recent progress in the implementation of the Global Strategy for Plant Conservation-a global perspective. Rodriguésia [online], 69(4): 1489-1511.

Solomon J., Shulkina T., Schatz G.E. (Eds.) (2014): Red list of the endemic plants of the Caucasus: Armenia, Azerbaijan, Gerogia, Iran, Russia, and Turkey. Missouri Botanical Garden Press, St. Louis: 451 pp.

Stafleu Frans A., Cowan Richard S. (1976-1988) Taxonomic literature: a selective guide to botanical publications and collections with dates, commentaries and types. 2nd ed. Utrecht: Bohn, Scheltema \& Holkema.

Tahtadzjan A.L. (1954) Flora Armenii, 1. Lycopodiaceae-Fumariaceae. Erevan, Publishing House of the Academy of Sciences of Armenian SSR: 293 р. [Тахтаджян А.Л. (ред.) (1954) Флора Армении, 1. Lycopodiaceae-Fumariaceae. Ереван, Издательство Академии наук Армянской ССР: 293 c.]

Talybov T., Novruzova E., Askerov A. (2014) New taxa of ferns in the flora of Nakhchivan AR. Proceedings of Azerbaijan NAS, Biological and medical sciences, 69(2): 102-106. [Talıbov T., Novruzova E., Osgərov A.M. (2014) Naxçıvan MR florasında qijıların yeni taksonları. AMEA-nın Xabarlari, Biologiya va tibb seriyast, 69(2): 102-106]

Talybov T.G. (2001) On a new family Adiantaceae for Nakhchivan flora (Azerbaijan). Journal of Botany. Moscow \& Leningrad (St. Petersburg), 86(6):
171. [Талыбов Т.Г. (2001) О новом семействе Adiantaceae для флоры Нахичеванской АР (Азербайджан). Ботанический журнал. Москва и Ленинград (Санкт-Петербург), 86(6): 171]

Turland N.J., Wiersema J.H., Barrie F.R., Greuter,W., Hawksworth, D.L., Herendeen P.S., Knapp S., Kusber W.-H., Li D.-Z., Marhold K., May T.W., McNeill J., Monro A.M., Prado J., Price M.J., Smith G.F. (2018) International Code of Nomenclature for algae, fungi, and plants (Shenzhen Code) adopted by the Nineteenth International Botanical Congress Shenzhen, China, July 2017. Regnum Vegetabile 159: i-Xxxviii + 1-254. doi.org/10.12705/Code.2018

\section{Azərbaycanın vaskulyar (damarlı) bitkiləri: qujıkimilərin və çılpaqtoxumluların yenilənmiş məlumat siyahısına əlavə}

\section{Rəşad A. Səlimov \\ Pərvanə X. Qaraxani \\ Zenfira S. Oliyeva \\ AMEA Botanika İnstitutu, Badamdar şossesi 40, Bakı, AZ1004, Azarbaycan}

Bitki növlərinin yenilənmiş məlumat siyahısı, müəyyən regionda mövcud olan flora haqqinda bilikləri genişləndirməklə ictimaiyyəti məlumatlandırmaq və bitki müxtəlifliyini qorunmasının fundamental əsasını təşkil edir. Bu cür nailiyyətlər Bitkilərin Qorunmasının Qlobal Strategiyası Hədəf 1-in həyata keçirilməsi ilə sıx bağlıdır. Bu məqalədə Qafqazdakı fitomüxtəlifliyin əsas mərkəzlərindən biri olan Azərbaycanın çiçəksiz vaskulyar (damarlı) bitkilərinin yenilənmiş nomenklatur məlumat siyahısına əlavələr verilmişdir. Məlumat siyahısı, Azərbaycan florasında rast gəlinən çiçəksiz vaskulyar (damarlı) bitkilərin taksonomiyası və nomenklaturas1, təbii və ksenofit bitkilərin qəbul edilmiş adların və sinonimlərinin yenilənmiş siyahısına dair informasiyaları ehtiva edir. Bundan əlavə, onların botaniki-coğrafi rayonlar üzrə paylanması və həyat formaları, nadirlik və endemizm statusu təhlil edilmişdir. Məlumat siyahısına Azərbaycanın təbii və ksenofit çiçəksiz vaskulyar (damarlı) bitkilərinin 22 fəsiləyə və 50 cinsə aid olan 115 növ, 27 növdaxili taksa (yarımnöv və variasiya) və 11 təbii hibridləri daxildir. "Azərbaycan Florası"nın I cildi nəşr olunduqdan sonra müxtəlif tədqiqatçılar tərəfindən 50-yə yaxın yeni taksonun (növ, yarımnöv və variasiya) əlavə olunduğu müəyyən edilmişdir. Müvafiq bitki qruplarının son filogenetik və sistematik tədqiqatlarına əsasən, 28 taksonun arasında nomenklatura dəyişiklikləri edilmişdir. Müasir 
nomenklatura məlumat siyahısı Azərbaycanın elektron florasının hazırlanması üçün əsas mətnə çevriləcək və gələcək taksonomik, ekoloji, fizioloji, etnobotanik və fitokimyəvi tədqiqatlar üçün zəruridir.

Açar sözlor: Azarbaycan, qijıkimilar, çılpaqtoxumlular, vaskulyar (damarlı) bitkilar, taksonomiya

\section{Сосудистые растения Азербайджана: дополнения к обновленному списку птеридофитов и голосеменных}

\section{Рашад А. Салимов}

Парвана Х. Гарахани

Зенфира С. Алиева

Институт Ботаники НАНАзербайджана, Бадамдарское шоссе 40, Баку, AZ1004, Азербайджан

Обновленный контрольный список видов растений расширяет знания о флоре определенного региона и имеет фундаментальное значение для информирования общественности и сохранения разнообразия растений. Достижения такого рода тесно связаны с реализацией Глобальной стратегии по сохранению растений (задача 1). В данной статье представлены дополнения к обновленному номенклатурному контрольному списку нецветковых сосудистых растений Азербайджана, одного из основных центров фиторазнообразия на Кавказе. Информация о таксономии и номенклатуре сосудистых нецветковых растений, обновленный список принятых названий и основных синонимов таксонов местных и ксенофитных растений, известных в Азербайджане, представлены в контрольном списке. Кроме того приведет количественный анализ их распределения и жизненных форм, редкость и эндемический статус. Он включает 115 видов, 27 внутривидовых таксонов (подвидов и вариаций) и 11 природных гибридов нативных и натурализованных нецветковых сосудистых растений Азербайджана, принадлежащих к 22 семействам и 50 родам. Было установлено, что после публикации 1 тома “Флора Азербайджана" различными исследователями в него были внесены сведения приблизительно о 50 новых таксонах (видах, подвидах и вариациях). До и после публикации I тома Флоры Азербайджана были обнаружены новые сведения о 50 новых таксонах (видах, подвидах и вариациях) различных исследователей. Согласно недавним филогенетическим и систематическим исследованиям соответствующих групп растений среди 28 таксонов были сделаны номенклатурные изменения. Современный номенклатурный список необходим для развития будущей систематики, экологии, физиологии, этноботаники и фитохимии в Азербайджане и станет ключевым основой для развития электронной флоры Азербайджана.

Ключевые слова: Азербайджан, птеридофиты, голосеменные, сосудистые растения, таксономия 